\title{
Combating Adult Illiteracy in the People's Republic of Poland (on the Example of Selected Documents of the Ministry of Education and the Office of the Government Plenipotentiary for Combating Illiteracy in 1949-1951)
}

From today's perspective, combating illiteracy seems like cultural prehistory. And yet it was a much more recent problem, still present during the early years of the People's Republic of Poland (PRL).

It is interesting to see how the state attempted to eliminate the phenomenon. How it tried to "find" the illiterate in the society and encourage them to learn. How they were helped so that they could attend courses. Answers to those and other questions can be found in, e.g. the Archives of New Records (AAN) in Warsaw, in the documents of the Ministry of Education and of the unit: the Office of the Government Plenipotentiary for Combating Illiteracy (BPRdoWA). The specified archival material is even more interesting because sometimes it constitutes a record of the correspondence and official notes, which, as one might expect, were not intended for publication.

The process of combating illiteracy has already been discussed ${ }^{1}$, which is why this article focuses only on some of the more interesting moments of its planning and implementation. It uses example conference and inspection reports. The efforts to combat illiteracy were one of the nationwide operations undertaken by the PRL government. It started with an act regarding the elimination of illiteracy passed in $1949^{2}$. On its basis Stefan Matuszewski became Government

\footnotetext{
* e-mail: magdalenabudnik@interia.pl; University of Bialystok, Faculty of Philology, Institute of Polish Philology, 15-420 Białystok, Plac Uniwersytecki 1.

${ }^{1}$ Cf. i.a. S. Mauersberg, M. Walczak, Szkolnictwo polskie po drugiej wojnie światowej (1944-1956), Warsaw 2005, pp. 249-253; P. Osęka, Naucz się czytać, napisz Stalin, "Gazeta Wyborcza" 2009, issue 167, pp. 23-24; S. Majewski, Likwidacja analfabetyzmu w Polsce w okresie powojennym (w 40-lecie ustawy o likwidacji analfabetyzmu), "Nowa Szkoła" 1989, issue 7, pp. 435-440; D. Jarosz, Książi pod strzechy. Z badań nad politycznymi uwikłaniami czytelnictwa wsi polskiej w latach 1949-1956, in: Z badań nad książka i księgozbiorami historycznymi, Warsaw 2008.
}

${ }^{2}$ The Illiteracy Elimination Act of 07 Apr 1949, J. of L. No. 25 Item 177. 
Plenipotentiary for Combating Illiteracy. The state established the Chief Social Commission for combating illiteracy as well as voivodship, poviat and communal commissions. The official completion of the project was announced in December $1951^{3}$. After three years of work, 600,000 illiterate and semi-illiterate persons up to the age of 50 had been trained. The report of the government plenipotentiary on eliminating illiteracy as a mass phenomenon of 21 Dec 1951 included a more "optimistic" figure of 845,402 persons who were registered and who had been taught how to read and write ${ }^{4}$. The difference is chiefly a result of balancing the number of registered persons and those who completed the training courses. Many of the registered persons did not start the training or stopped attending the classes at some point. There were also instances such as the one described in the report after the inspection in Silesian Voivodship:

During the June registration many persons who refused to fill out the questionnaire or filled it out in an illegible manner /e.g. pharmacists, students, etc./ were classified as the illiterate or semi-illiterate ${ }^{5}$.

The reported figure applied to the operation alone. If one adds the number of persons trained in the years prior to the operation and after, the resulting figure would exceed 1 million people who underwent basic training ${ }^{6}$.

The authorities strived to include the entire society by expanding the operation as much as possible. Towards that end they used propaganda present in the press, the radio, films and propaganda specific for separate social groups (students, soldiers, paramilitary youth organisation members, prisoners, specific professional groups, etc.)

During a conference on the establishment of "the Social Council for combating illiteracy" Leonard Sobierajski from the Wieś magazine proposed to:

"(...) gather a team of writers, who being aware of the issue, shall start a press campaign. The fact of training 40,000 or 50,000 illiterate persons will not solve the issue; it is necessary to use all available means to ensure the success of the operation. It must be indicated that the path to promotion of peasant or worker masses leads through education. The Wieś editorial board devotes an entire column in every issue to the operation of combating illiteracy"7.

${ }^{3}$ Cf. AAN, BPRdoWA, ref. no. 12, meeting report of the committee of the Chief Social Commission for Combating Illiteracy of 11 Dec 1951.

${ }^{4}$ AAN, BPRdoWA, ref. no. 169, 1. 8.

${ }^{5}$ AAN, BPRdoWA, ref. no. 61, 1. 2.

${ }^{6}$ S. Mauersberg, M. Walczak, op. cit., p. 251.

${ }^{7}$ AAN, Ministry of Education, ref. no. 3449, 1. 375. 
The 1950 "Trybuna Robotnicza" included a statement by Minister Matuszewski who openly declared that:

The issue of combating illiteracy cannot be treated separately from international political events (...) neither can it be considered separately from the struggle of progressive forces against war instigators. It is inextricably linked to the entirety of political, economic and cultural issues. The struggle cannot be fully developed until there are still citizens in this country who are not made aware, particularly those who cannot read or write ${ }^{8}$.

Apart from many "normal" articles reporting on the course of the efforts for combating illiteracy, another interesting form of propaganda were press satire pieces. Those were mainly small sketches with short descriptions. "Dziennik Łódzki", for example, published a sketch where an elderly man who is reading something waves his hand to leave him alone. The caption read: "The hell with this fight with illiteracy! Ever since they taught grandpa how to read, you cannot take him away from his books and newspapers". Pierwsi z kolei [First in line] - this wordplay was used for reporting the elimination of illiteracy in the railway operatives' union ["kolej" - a word with dual meaning of "railway" and "order, sequence" $]^{10}$.

Apart from the press, the radio was an important carrier of propaganda. The authorities even established a special Radio Sub-commission at the Government Plenipotentiary for Combating Illiteracy. A decision was made that during the "Illiteracy Combating Week" the slogans were to be repeated often throughout the day. The goal was for the citizens to hear numerous appeals, speeches, reports, discussions and radio dramas from a model lesson ${ }^{11}$. One example of such a radio show was "An interview with persons who thanks to combating illiteracy gained reading and writing skills and entered the ranks of conscious citizens"12.

The film's potential had also been recognised. A post-meeting report of the Editorial Commission of the Chief Commission for Combating Illiteracy stated that "the Commission ought to make contact with Film Polski (film company) to develop a slide primer of films for reader units so that school children could enjoy interesting views and at the same time learn to read or practice reading"13.

${ }^{8}$ Walka z analfabetyzmem musi być prowadzona równolegle z walka o produkcję, "Trybuna Robotnicza" 1950, (8 Mar), p. 7.

${ }^{9}$ Skutki walki z analfabetyzmem, "Dziennik Łódzki" 1951, issue 97 (9 Apr), p. 7.

${ }^{10} \mathrm{Na}$ apel CRZZ pierwsi kolejarze zlikwidowali w swoim zwiazku analfabetyzm, "Express Wieczorny Warszawa" 1951, issue 105 (17 Apr), p. 4.

${ }^{11}$ An example of a radio announcement supporting the efforts to combat illiteracy: Dom television series, episode 6: Nosić swoja skórę, time: 17:53.

${ }^{12}$ AAN, BPRdoWA, ref. no. 204, 1. 3.

${ }^{13}$ AAN, BPRdoWA, ref. no. 39, 1. 36. 
Ever since the beginning, and, it seems, throughout the operation, there were some problems. When presenting the result of the registration, the Department of Education of the Wrocław School District (10 Dec 1947) concluded that:

(...) The main difficulty in registration operations was caused by people's stubbornness. The illiterate avoided the registration for the fear of possible forced learning. (...) Considering huge distances (and low numbers of registrants) it was impossible to reach every location, particularly as the population was often out or was hiding on purpose $^{14}$.

Even mud and the lack of proper infrastructure prohibited the officials from reaching the population. In a letter dated 1 Feb 1947, the Office of Studies and Statistics concluded that: "(...$)$ but the date of the registration should be delayed past 15 March, preferably to the beginning of May when the roads and paths will be dry". ${ }^{15}$

The course of the efforts to combat illiteracy, at its every stage, was carefully supervised by the Ministry of Education. Inspections constituted one form of such supervision. The operation began with a registration of the illiterate. An inspection at the Gdańsk Shipyard (on 4 and 6 Oct 1949) resulted in a report which specified the methods of finding the illiterate among the shipyard operatives:

386 persons at the Shipyard unable to read or write were registered in June this year. Many people avoided registration. Currently, the number of registered illiterate persons increased to 736 (350 persons registered during an additional registration), supplementary registration is ongoing. All workers must sign the payment confirmation list. Those who cannot sign it and write in words the amount they earn are registered as illiterate or semi-illiterate persons ${ }^{16}$.

A report from Łódź included yet another (at surely more effective) method of finding the illiterate:

Auxiliary registration is conducted on a permanent basis in residency registration offices, insurance agencies, banks and other institutions where an illiterate person is identified while attending to official matters. If a person cannot sign a document, such a case is reported to the field social commission ${ }^{17}$.

Basic training courses faced many problems. In the section "Dezyderaty i życzenia Wojew. Komisji Społecznej" [Propositions and requests of Voivodship

\footnotetext{
${ }^{14}$ AAN, Ministry of Education, ref. no. 3449, 1. 311-312.

${ }^{15}$ Ibidem, 1. 63.

${ }^{16}$ AAN, Ministry of Education, ref. no. 3446, 1. 9.

${ }^{17}$ Ibidem, 1. 59.
} 
Social Commission], a report after an inspection of the work of the Social Commission for Combating Illiteracy in Wrocław (3-5 Oct 1949) stated: "Influence centrally the authorities responsible for electricity distribution so that conservation limitations would not divert electricity from basic training courses"18. The problem of insufficient lighting was often raised in official documents: "Lighting is insufficient at virtually all classes. Too few small kerosene lamps make work difficult" $" 19$. At that time, the easiest way to improve lighting was to deliver more gas and kerosene lamps: "Make efforts to improve lighting during basic training courses by delivering more lamps" 20 .

In a document from the Education Department of the School District in Łódź, an inspector bitterly noted:

Based on conducted inspections and incoming reports from School Inspectorates it must be stated that the illiterate report for the training very reluctantly. Considering the fact that in the cities, where Workers' Unions use such sanctions as: exclusion from the Union, suspending clothing materials and revoking holidays, it is not always successful, then in the countryside the issue in many instances is very serious" ${ }^{21}$.

In the time when empty stores were not an uncommon sight, facilitating (or hampering) access to uncommon material must have been a strong argument for the illiterate to decide to start basic training: "Zgierz supplied the illiterate who participate in course with special ID cards, using which they could skip the queue to acquire staple products" 22 .

Extended forms of social aid were another form of encouraging people to participate in the courses. An example of a post-inspection report in Katowice (4-5 Oct 1949):

Various forms of social aid in Silesian Voivodship are used /acquiring artificial fertilizer, meal sponsoring, supplying glasses, free holidays, benefits, etc./ but not in all poviats. A social aid campaign is particularly needed at the workplace. Company councils and directors have showed too little interest and initiative in this, which is reflected in the turnout ${ }^{23}$.

A similar example can be found in a report from Rzeszów (7 Oct 1949): "In order to ensure good turnout at training courses, stimulate social organisations

\footnotetext{
${ }^{18}$ Ibidem, 1. 20.

${ }^{19}$ Ibidem, 1. 75.

${ }^{20}$ AAN, Ministry of Education, ref. no. 3446, 1. 76.

${ }^{21}$ AAN, Ministry of Education, ref. no. 3449, 1. 37.

${ }^{22}$ AAN, Ministry of Education, ref. no. 3446, 1. 60.

${ }^{23}$ Ibidem, 1. 29-30.
} 
to organise social aid for the illiterate attending the courses and their families through collective help in agricultural works, organising substitutes for work, meal sponsoring for those learning directly after work, care over children of mothers during their training, shuttle service from remote locations, facilitating participation in cultural events (theatre, concerts, cinema, trips), financial aid, etc" ${ }^{24}$.

Some help for women must have been offered since: "Community organisations (Women's League, Z.M.P., Z.H.P.) look after the children of mothers who participate in the training (...)" While "for mothers with small children, S.P., Z.M.P. and the Women's League organise personal sessions" ${ }^{26}$. Course participants could also be dismissed from work for the time of the training and received free medical care ${ }^{27}$.

A post-inspection report from Toruń (5 Oct 1949) indicated an entirely different problem, this time of a psychological nature. It seems that the illiterate were ashamed, and not only in relation to their families and neighbours:

\section{Audit of primary school children in Chełmża}

Primary school no. 2 offers two courses: one for men and one for women. The division was requested by the women who were ashamed in relation to the men (...)

Audit of basic training course in Grzywna (Chełmża commune village)

(...) Absent students are busy during the sugar-making campaign. The village "mocks" the illiterate. Country Commission and local organisations did not create a friendly attitude amongst the community towards the course participants $(\ldots)^{28}$

The struggle to combat illiteracy was one of the highest points in the history of early-PRL. In it, however, the authorities strove to build a modern socialist state. Therefore, they never abandoned their ideological motivation. During a conference with the press, Tadeusz Pasierbiński, Ph.D., the director of the Department of Education and Culture of Adults at the Ministry of Education, stated, e.g.:

Education is an instrument with the use of which the state shapes new citizens for the fulfilment of its goals. Poland's position is that every school, every educational entity is an agency of the Education institution, which fulfils the goal of maintaining the achievement of people's democracy, freedom and the ability to live together within the large family of the nations of the world ${ }^{29}$.

\footnotetext{
${ }^{24}$ Ibidem, 1. 72.

${ }^{25}$ Ibidem, 1. 6.

${ }^{26}$ AAN, Ministry of Education, ref. no. 3446, 1. 37.

${ }^{27}$ Ibidem, 1. 70.

${ }^{28}$ Ibidem, 1. 39-40.

${ }^{29}$ AAN, Ministry of Education, ref. no. 3449, 1. 318.
} 
Therefore, it comes hardly as a surprise that the program's list of training results, apart from such areas as reading, writing or speaking, also listed:

Learning about Poland and the contemporary world.

Orientation on the map of Poland: Poland's borders /the western and the maritime borders in particular/, rivers: the Vistula and the Oder, mountains, major cities and ports. What the People's Republic offers to peasants and workers /agricultural reform, nationalisation of heavy industry, etc./ Who is the president of Poland. What is the Sejm. List Slavic nations and countries and what is associated with them. The threat of Germany and fascism ${ }^{30}$.

Archival documents indicate the operation was conducted simultaneously among various institutions and social groups and organisations. The report by the Voivodship Social Commission for Combating Illiteracy in Warsaw read:

(...) A representative of S.P. (Służba Polsce) discussed the issue of combating illiteracy within the ranks of S.P. Young cadets crave for education. During the $1^{\text {st }}$ camp, 700 illiterate persons from specific regions of Poland have been trained ${ }^{31}$.

The Służba Polsce organisation was a paramilitary organisation conducting compulsory civil defence training, military training and ideological indoctrination among the youth ${ }^{32}$. Reading and writing training was conducted in-camp ${ }^{33}$.

The document unit of the Ministry of Education included documents regarding the training of Security Service (Urząd Bezpieczeństwa, abbreviated to UB) operatives, systematic supplementary education of adult inmates, repolonisation courses for repatriates, supplementary training for war invalids, training at Women's Protection Homes, Polish Army officers, Milicja Obywatelska officers, Ministry of National Security employees ${ }^{34}$.

The authorities also tried to promote the effects of the efforts for combating illiteracy. Towards that end they used letters and testimonials of the illiterate, their literary output, their biographies (often dramatic) written down in the form of memoirs and exhibitions.

${ }^{30}$ Ibidem, 1. 257.

${ }^{31}$ AAN, BPRdoWA, ref. no. 34, 1. 18.

${ }^{32}$ Act of 25 Feb 1948 on the general obligation to attend civil defence, physical education and military training by the youth and on the organisation of the matters of physical culture and sports, J. of L. No. 12, Item 90.

${ }^{33}$ An example of basic training for cadets: Dom television series, episode 5: Ponad 200 czwartków, time: 39:31.

${ }^{34}$ AAN, Ministry of Education, ref. no. 3305, 1. 43 [U.B.], 1. 59 [inmates], 1. 71 [repatriates], 1. 103 [war invalids], 1. 200-203 [W.P.H.], 1. 204 [officers], 1. 206 [M.O.], 1. 209 [employees of the Min. of Nat. Sec.] 
This is one such example of a letter of a former illiterate person, by Zygmunt Zwierzak addressed to the Communal Commission for Combating Illiteracy in Dąbrowa:

I could not write or read 3 months ago. Today, I can write a letter by myself. I am 24 years of age before the war I could not attend school because I worked as a boy at a brickyard. I worked for the whole family and there were 7 of us. Now, in free Poland, I enrolled into the training course and I'm glad I can finally read and write in Polish. I would also like to thank the State for organising such courses and I would like all those like me to take advantage of them ${ }^{35}$.

Another letter from the same town:

I am glad I am learning at the basic training course in our village. A few months back I could not read or write. Neither before the war or under the Germans I could not attend school. Now that we have freedom I can learn and I intend to continue my education. I can already read gromada and other newspapers by myself and I will borrow books from the library. I would like to appeal to all women in Poland so that there isn't a single one in the country that could not write or read. I wish to thank all who organised the courses mainly the communal Commission and our Manager who is teaching $\mathrm{us}^{36}$.

The creative output of already trained former illiterate persons was also often published. This is an example of a biography of a basic course graduate and his poem, which he wrote under the impression of an image in a primer for adults:

Born on 2.1.1892 in Stanisław Dolny. When I was 3, my right arm and leg got paralysed. I did not attend school as there was none where I lived so I'm a self-taught person because I can read and write without learning that anywhere. When I was 18 I was employed by a company to construct navigable canals in the position of lubricator and when I got my first pay I cried with joy that I, a cripple, earned money with his own hands. 1919 I married and had two daughters. During German occupation I was a trader. I bought pieces of garments from German soldiers, leather and ready footwear and I sold it to people in the village. I currently repair footwear. I work with my left hand and only with my four fingers as I suffer from fifth finger contracture. I do not acquire no supplies from anywhere. My name is Oprychał Józef ${ }^{37}$.

${ }^{35}$ AAN, BPRdoWA, ref. no. 222, 1. 38. Original syntax, spelling and punctuation have been preserved.

${ }^{36}$ AAN, BPRdoWA, ref. no. 222, 1. 39.

${ }^{37}$ AAN, BPRdoWA, ref. no. 204, 1. 59. 
Co widziatem na obrazku

Budują fabryki, osiedla wspaniałe Sobie na pożytek, Ojczyźnie na chwałę.

Bo polski robotnik okryty jest chwałą Odbudujemy Polskę piękną i wspaniałą.

Bo polski robotnik ma tę wadę w sobie -

Przestanie pracować aż go złożą w grobie.

Tu zaś rolnik pługiem czarną ziemię orze.

Bo się wiosna zbliża, trzeba zasiać zboże.

Niech pracę rolnika błogosławią nieba -

By w naszej Ojczyźnie nie zabrakło chleba.

A wrony za pługiem na skiby siadają, One to szkodliwe owady zjadają.

$\mathrm{Na}$ karych konikach sierść się połyskuje

Parobek ich godzi, z bata potrzaskuje.

To nasz port nad morzem, tu dźwigi pracują

Towary z okrętów na ląd wyładują.

Tu wielkiej potrzeba techniki i siły,

By bałwany morskie portu nie rozbiły.

Gdy bałwany morskie o port uderzają Wtenczas robotnicy ciężką pracę mają.

A tu znów spod dłuta aże ogień pryska,

Tu robotnik toczy do maszyn łożyska Tu idzie robota, motory turkoczą.

Bo i inne rzeczy tutaj także toczą.

\section{What I saw in the picture}

They are building factories, magnificent housing complexes -

Benefit for them, for the glory of the Motherland.

Because the Polish worker is clad in glory -

We will rebuild Poland beautiful and magnificent.

Because the Polish worker has that innate flaw -

He will stop working when they put him to his grave.

Here the farmer ploughs the black earth. Because spring is coming, cereal must be sown.

May the heavens bless the farmer's work $-$

So that our Motherland never be short of bread.

And the crows land on the ridges behind the plough,

They eat the pests.

Manes glisten on black horses

The farm-hand strikes them, snaps the whip.

This is our port on the sea, that is where cranes work

Unloading the goods onto the land.

This where great technology and strength is needed,

So that sea breakers do not destroy the port.

When the breakers hit the port The workers' work is hard.

A here flames burst from under the chisel,

Here the worker turn machine bearings This where work happens, where engines rumble.

Because they also turn other things here. 
Po pracy w świetlicy bawią się wesoło.

Jest tu założone amatorskie koło.

Starsi znów gazet i książki czytają

I fachowe pisma też w świetlicy mają

Panienka w świetlicy służy dobrą radą.

Przeczytane książki z powrotem układa.
When the work is done they relax merrily in the common room.

An amateur group operates from here.

Those older read newspapers and books once more

And there are as well professional magazines in the common room

A lass offers her advice in the common room.

She puts books back in order.

An exhibition entitled "Jak Polska Ludowa zlikwidowała analfabetyzm" [How the People's Republic eliminated illiteracy] was also supposed to familiarise society with the results of the operation. Its script indicated a special section called: "Nauka umożliwiła mi awans społeczny i zawodowy" [Education enabled my social and professional promotion]. Underneath were displayed photographs with captions confirming the (often spectacular) social promotion of basic training graduates, e.g.: "Elżbieta Kowalska, she used to be a cleaner, after the professional training she has become a station traffic orderly in Gogolewo". And another caption: "Karol Kaniora, a sharecropper from Wojsław collective, Grodzisk Poviat - he became village leader, chairman of the production cooperative and a plenipotentiary for combating illiteracy".

Even though the operation was concluded after three years, the authorities realised that the efforts for combating illiteracy had to be ongoing. Therefore, the authorities established the Readership and Book Council ${ }^{38}$ and later issued an ordinance by the Minister of Education and the Minister of Culture and Arts of 9 Apr 1953 regarding the organisation of readership units among basic training graduates ${ }^{39}$. The main issues raised by the units included: the fight for social liberation; the construction of the basis of socialism in the People's Republic; model, friendship, help for USSR; fight for peace - as one might rightly expect, the topics rather discouraged people from participating in meetings, which were not attended by many.

Any assurances that illiteracy was eliminated from PRL were not entirely true. 300,000 people did not appear for the classes, several thousand more terminated their education before it ended. The one-time operation did not bring about expected results ${ }^{40}$.

\footnotetext{
${ }^{38}$ Resolution No. 4242 of the Committee of the Government of May 1952.

39 The units also offered a chance to study the curriculum of elementary grades and pass exams regarding particular subjects and grades. That was made possible through a Resolution of the Minister of Education of 1 Jun 1953 regarding examinations for external students within the scope of primary school curriculum. St. Majewski, op. cit., p. 439.

${ }^{40}$ S. Mauersberg, M. Walczak, op. cit., p. 249-253.
} 
The intentional selection of themes included in the material for teaching adult illiterate persons may cause some doubts. When considering the primers it is difficult not to assume that ideology was much more important than combating illiteracy. Numerous methodological errors also support this assumption. The primers prepared the students not for learning how to read and write, but mainly for participating in the socialist reality.

\title{
Bibliography
}

AAN, Ministry of Education, ref. no. 3305, ref. no. 3446, ref. no. 3449.

AAN, BPRdoWA, ref. no. 12, ref. no. 34, ref. no. 39, ref. no. 61, ref. no. 169, ref. no. 204, ref. no. 222. Jarosz Dariusz, Ksiażki pod strzechy. Z badań nad politycznymi uwikłaniami czytelnictwa wsi polskiej w latach 1949-1956, in: Z badań nad ksiązka i księgozbiorami historycznymi, Uniwersytet Warszawski. Instytut Informacji Naukowej i Studiów Bibliologicznych, Warsaw 2008. J. of L. No. 25 Item 177.

J. of L. No. 12 Item 90.

Majewski Stanisław, Likwidacja analfabetyzmu w Polsce w okresie powojennym (w 40-lecie ustawy o likwidacji analfabetyzmu), "Nowa Szkoła" 1989, issue 7, p. 435-440.

Mauersberg Stanisław, Walczak Marian, Szkolnictwo polskie po drugiej wojnie światowej (1944-1956), Polskie Towarzystwo Pedagogiczne Zarząd Główny, Warsaw 2005.

Na apel CRZZ pierwsi kolejarze zlikwidowali w swoim zwiazku analfabetyzm, "Express Wieczorny Warszawa" 1951, issue 105 (17 Apr), p. 4.

Osęka Piotr, Naucz się czytać, napisz Stalin, "Gazeta Wyborcza” 2009, issue 167, pp. 23-24.

Resolution No. 4242 of the Committee of the Government of May 1952.

Skutki walki z analfabetyzmem, "Dziennik Łódzki" 1951, issue 97 (9 Apr), p. 7.

Walka $z$ analfabetyzmem musi być prowadzona równolegle z walka o produkcje, "Trybuna Robotnicza" 1950, (8 Mar), p. 7.

Magdalena Budnik

\begin{abstract}
Combating Adult Illiteracy in the People's Republic of Poland (on the Example of Selected Documents of the Ministry of Education and the Office of the Government Plenipotentiary for Combating Illiteracy in 1949-1951)
\end{abstract}

(Summary)

The subject of this article is combating adult illiteracy in the People's Republic of Poland. The existing knowledge concerning the topic has been supplemented with the analysis of the archival documents, currently being in possession of the Central Archives of Modern Records in Warsaw. It describes how illiterates were recognised in the society, in what way they were encouraged to train new skills and how attending the courses was made possible for them. The analysed documents include censors' reviews of manuals, press articles, letters wrote by former illiterates and other valuable records. 
The communists were combating illiteracy not only in the name of the social progress, but mostly motivated by their quest to broaden the possibilities of ideological indoctrination - during the courses organised for illiterates and later on. This is why the selection of manuals and other publications addressed to former illiterates was propagandist. The strategic importance of the matter was expressed by Vladimir Lenin himself: "Socialism cannot be built by illiterates" (W. Ozga, Education in the six-year-plan and the revolutionary changes of the society and economics in the People's Republic of Poland, Warsaw 1951, p. 124).

Keywords: adult illiteracy in the People's Republic of Poland, Ministry of Education, combating illiteracy in the years 1949-1951 